\title{
Journal of the International Phonetic Association
}

\author{
(formerly Le Maître Phonétique)
}

\section{NOTES FOR CONTRIBUTORS}

Policy.-The Journal of the International Phonetic Association, formerly entitled Le Maître Phonétique, is concerned with all aspects of phonetics and phonology, on which subjects it publishes articles, specimens, correspondence, and reviews. The official language is English, though contributions in other languages of wide currency will be published as the Editor thinks fit.

Style.-Contributions should be submitted in typewritten form, in double spacing with wide margins, on one side of the sheet only, on quarto or A4 paper. Phonetic transcriptions should make use of the symbols and conventions of the Association's alphabet. If phonetic or other symbols have to be added to the manuscript by hand, they should where appropriate be identified in the margin by their grid co-ordinates shown in the journal's Reference Table of Phonetic Symbols (available from the Editor on request). Phonemic symbols should be enclosed in slants, but allophonic or generalphonetic symbols in square brackets, e.g. /tel/, [thet], [m]. Cited forms should be italicized, without quotation marks ; translational 'meanings' and quotations should be placed within sINGLE quotation marks. Technical terms and other words to which it is desired to give particular emphasis may be printed in sMaLL CAPITALS, but NOT in italics. Footnotes should be avoided as far as possible; where essential they should be numbered consecutively throughout the manuscript. References are to be made IN THE TEXT by giving in parentheses the name of the author and the year of publication, and where relevant the page or pages referred to : e.g. '... (Jones, 1963 : 452-3) . . '. All works so referred to should be listed, with full bibliographical details and in alphabetical order, at the end of the article. Names of books should be italicized, but titles of articles placed between single quotation marks.

Proofs and offprints.-Two copies of proofs will be sent to the author (or his nominee), who will be expected to correct them and return them to the Editor, by airmail where appropriate, within ten days of receipt. Upon publication, fifty copies of a contribution will be supplied to the author free of charge ; further offprints may be purchased at cost. 


\section{Publications of the International Phonetic Association}

The Principles of the International Phonetic Association (1949). A description of the International Phonetic Alphabet and the manner of using it, illustrated by texts in 51 languages. $60 \mathrm{p}$ (to members 40p).

Chart of the International Phonetic Alphabet (1951). 2p (to members 1p).

The Eistory and Meaning of the Term " Phoneme" (1957, reprinted with corrections 1975). By D. Jones. 40p (to members 25p).

Miscellanea Phonetica II (1954). Articles by D. Jones, A. Martinet, E. V. Pike and E. Fischer-Jørgensen. 25p (to members 18p).

Miscellanea Phonetica III (1958). Articles by P. LAdefoged, M. H. Draper and D. Whitteredge, M. R. Wise, E. Matteson and K. L. Pike, and G. Hammarström. 30p (to members 20p).

Differences between Spoken and Written Language (1948). By D. JoNes. 5p (to members $3 p$ ).

La Phonétique et ses Applications (1929). By Paul Passy. 5p (to members $3 \mathrm{p}$ ).

Notes on the Dialect of Nidderdale (Yorkshire) (1922). By M. L. ANNAKIN. 5p (to members 3p).

The Russian i-i Phoneme (1947). By S. C. Boyanus. 3p (to members 2p).

Back issues of Le Maître Phonétique (1886-1914; 1923-1970) may be obtained from Swets \& Zeitlinger B.V., Backsets Department, Heereweg $347 \mathrm{~b}$, Lisse, Netherlands, to whom enquiries should be sent.

Back issues of the Journal (1971-1976) may be obtained from the Secretary of the Association at the following prices :

1971-1974: $£ 2.00$ per volume (to members $£ 1 \cdot 50$ )

1975-1976: $£ 3 \cdot 00$ per volume (to members $£ 2 \cdot 25$ )

Printed in England by Stephen Austin and Sons, Ltd., Hertford. 